\title{
The Contribution of the Urbanization of the Information System on Urban Development in Casablanca (Morocco)
}

\author{
Mohamed Rtal*, Mostafa Hanoune \\ Laboratory TIM, FSBM, Hassan II University of Casablanca, Morocco
}

Received April 27, 2020; Revised May 21, 2020; Accepted June 23, 2020

Copyright ( $(2020$ by authors, all rights reserved. Authors agree that this article remains permanently open access under the terms of the Creative Commons Attribution License 4.0 International License

\begin{abstract}
In order for development to be sustainable, strong and rich, it must be established in a common vision of all activities of society, so that each party decides and chooses to form it in its own way. In this context, it was necessary to "have" a parallel roadmap for this concept of human city planning, which is the strategic development of information systems through the concept of city planning for an information system that should represent the contribution of the value of different citizens. Thus, the information system can be compared to the city area: If the latter is well built and well civilized, it is possible to raze a building in the heart of the area without jeopardizing the entire sector, and replace it with or rebuild another building. A study of the stages of this urban expansion would provide the researcher and actor with a clear view of how the city was expanded, its directions, and its horizons, and thus contribute to preparing and managing the urban area of the city, and from the most effective means to do so, we find new technologies that have added a lot to studies Geographical indications, including geographical information systems and remote sensing, which are of great importance, given the aerial photographs and archive data they provide.
\end{abstract}

Keywords Information System, Development, Casablanca, Urban Development

\section{Introduction}

Casablanca is experiencing a rapid increase in the urban population due to population growth, rural exodus and several other social, economic, etc. parameters. This urbanization, which introduces quite complex phenomena, has generated a multitude of problems: transport, lack of social facilities, environmental degradation, management of urban space, traffic overlaps etc. Human urbanization policies have created a need for an urbanization of information systems to control this phenomenon through the establishment of urban planning documents defining the rules for the control of urban activities. The urbanization of information systems is today positioned as a powerful decision-making tool, particularly with regard to the management and control of space. The integration of the spatial dimension, thanks to Geographic Information Systems (GIS), now makes it possible to locate information and organize data more precisely. Certain procedures in the urban information system are based on standard geographic documents. Thus the use of GIS is relevant for part of the work, especially urban.

From 1781, when the Spanish installed counters there, that the Spanish translation, Casa Blanca, spread. European traders settled there and at the beginning of the 19th century, the French obtained from Sultan Moulay Abdelaziz (1894-1908) to build a port. Casablanca, considered the first port of Morocco from 1920, it also became, in 1925, the first stopover of the Latécoère airlines (the future Aéropostal) connecting Toulouse to Dakar [1-2].

After the establishment of the Protectorate, Lyautey and his architect Henri Prost embark on the realization of the modern city center by building wide boulevards bordered by large and pretty buildings. It is in this city that the first factory will be built and that will be launched the first union. In 1950, Casablanca was a dynamic shopping center whose urban planning was booming.

In the aftermath of independence, Casablanca became a large urban concentration, which required control of its pace of development. This was the subject of the Urban Development Master Plan drawn up in 1985.

The construction of the Hassan II mosque gave 
Casablanca a spiritual, religious and tourist dimension.

The major projects were launched by His Majesty King Mohammed VI who may God glorify him, since his enthronement aiming to further consolidate the efforts concerning the improvement of the living conditions of the citizen of Casablanca.

\section{Urban Vision in Question: Evolution and Challenges of the City Casablanca}

The city of Casablanca has constituted an important cultural heritage with the mixture of many civilizations through the ages. This was reflected in its urban fabric, which made it regain a unique urban structure, but the latter has experienced in recent decades a kind of neglect and deterioration, which has affected most of its urban facilities, and this is mainly due to Economic, social and demographic problems, and with the increase of this problem, a set of interventions and strategies had to be undertaken in order to raise the standard of living of buildings and roads with all their components economic, social, cultural [3].

For Casablanca to remain a witness to a deep past, the urban policy of the city recently implemented an urban vision of information systems, which have proven in many areas their capacity to face the daily problems and challenges which are defined. Through the management of urban areas. Information systems are considered to be an effective mechanism for integrating different types of information. The system includes software and devices that allow the collection of information in a database, quality control, updating of data, information and analysis (logic and statistics) in a simple, fast and precise manner, with a visual display of this data in the form of a map.

\section{Information Systems and Their Role in Protecting Heritage}

The case of heritage cities has become more urgent than ever, because it has a very important cultural and historical value, because this heritage is the property of all humanity [5-6]. The processes that must be accomplished to preserve these heritage cities are mainly linked to the diagnosis and implementation of projects for the different architectural and urban components of these cities. If modern cities depend in their urban planning on the use of modern methods, then historical exploits with a complex and distinct fabric with significant historical and cultural weight require the use of very sophisticated scientific techniques, capable of diagnosing and analyzing the current situation and to highlight forecasts and future scenarios, in a global rescue and rehabilitation approach. Urbanization of information systems is an important tool for preserving geographic information linked to the nature of places, monitoring all resources, analyzing them and defining models for them, while monitoring the effects of tourism development because it is a tool basic and applied to analysis, and a means that displays tourist and archaeological sites in the form of geographical maps, helping to provide all the information and data that support tourism planning, such as:

- $\quad$ Residential buildings: those with artistic or personal value, such as the notables...

- $\quad$ Social facilities: traditional schools, bathrooms

- $\quad$ Religious installations: mosques, corners, shrines and cemeteries

- $\quad$ Tourist paths: paths and roads leading to the most important monuments of the city through signs and special signs

Casablanca, known as the "White City", is considered one of the most active and vibrant cities in Morocco. In a century, the humble village of Anfa managed to become a city with more than four million people to become one of the largest cities in Africa.

\section{The Problematic of the Study}

Casablanca occupies a key position on the Moroccan development map. Since the independence of Morocco and its control of the city of Casablanca, the Kingdom of Morocco has worked hard to develop it through a number of development projects, and the country has started to prepare plans and studies for development. Provided that infrastructure projects start, especially in coastal areas, because it is a large region which suffers from a demographic explosion and problems at different levels: political, administrative, sporting and cultural, this is extremely necessary with regard to the main problems of housing and infrastructure. In terms of development plan, urban master plan, zoning plan and finally the development plan of information systems to supervise town planning.

This situation poses the following problem "How to use a functional information system to carry out an urban and advanced planning of the city of Casablanca with a strategic orientation with transverse administrative objects?"

\section{Threatened Housing is A Feature of Most Areas of the Old City}

According to all the research and studies carried out in many old Moroccan cities, the phenomenon of housing threatening to collapse has become generalized, all the more so since this type of housing is no longer limited to one district and no other, but the phenomenon has become widespread in all districts and paths of ancient cities. The best example of this is the old city of Casablanca, which 
has seen an increase in the deterioration of its built environment over the past 20 years, which has led to the collapse of many houses, resulting in enormous loss of life and goods.

\section{Geographical Distribution of Buildings Threatened with Collapse in the Old City of Casablanca}

The spatial distribution of buildings at risk of collapse in the old city of Casablanca is characterized by the variation in their total number from one region to another, and with different degrees of severity, the official data of the city of Casablanca revealed that 6,338 buildings should be treated; of which 2,180 will be completely demolished, 956 will be partially demolished, while 2,921 buildings will be treated and rehoused 9,250 families, stressing that 3,995 families have been permanently resettled, while a residential offer has been made to house 2,106 families, 6,100 families out of 9,250 whose files have been processed. Figure 1 shows some photos of buildings threatened with collapse in Casablanca [7-9].

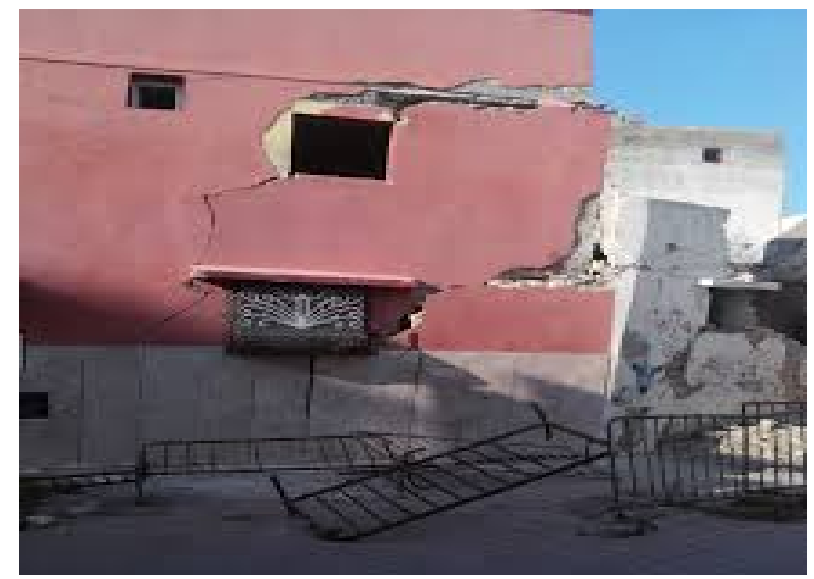

Figure 1. Photo of buildings threatened with collapse by an old fabric in Casablanca

\section{Urban Expansion of Information Systems in Urban Rehabilitation and Upgrading Programs for Heritage Protection}

Nowadays, the management of a city encompasses vast fields of competence. The population is in perpetual growth, it follows from it the needs for new resources and infrastructures growing. In addition, the process of urbanization of Information Systems consists first of all in studying the different functional sectors of Casablanca as metropolitan city (production, management, sale, etc.), in order to be able to implement the mapping, then to study the information system in the same way.
Mastering information has always been a major concern, at all levels and in particular that of power. This issue is essential, especially with regard to the management of heritage protection. The explosion of new technologies and information technology in all sectors of activity suggests an even faster development of global databases [10].

This approach begins with the inventory and capitalization of all the information in the Casablanca information system (databases, applications, services, etc.), while respecting its function, in order to rationalize and enhance human capital.

Therefore, the objective of the urbanization approach is to achieve the structure of the information system, which improves its performance and scalability. It thus gives Casablanca the means to develop its information system with full knowledge of the causes [11-12].

\subsection{The Role of Urbanization of Information Systems in the Diagnosis of the Physical State of Buildings}

The classification of buildings at risk of collapse depends on a number of indicators, mainly the "pathological" symptoms that appear on the structure of buildings vertically and horizontally. Several of these data are used to develop a classification of the degree of dangerous buildings, because they are classified into three levels of severity. The information system is used as a tool for this classification by collecting data directly in the field, through repeated visits to the field in order to diagnose it, and by creating a database, used to map, showing the distribution of the role which is threatened with collapse according to the degree of its gravity, on which to rely in most of the interventions undertaken by various institutions involved in the safeguarding of the ancient city.

\subsection{The Process of Urbanization of Information Systems}

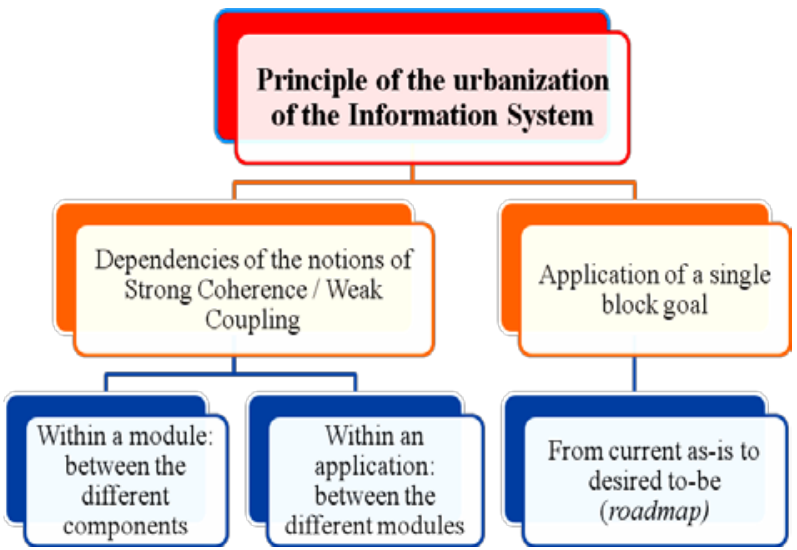

Figure 2. Principle of the urbanization of the Information System

The urbanization process aims to gradually improve the performance and management of the information system to make it a critical competitive advantage. For this, 
urbanization depends on an essential tool - mapping thanks to which the company will have a clear, documented and valued vision of its heritage.

The implementation of the mapping / urbanization approach will allow us to build a prototype and progressively responsive information system, able to better serve corporate strategy.

Figure 2 shows the different Principles of urbanization of the information system

\subsection{The Urbanization Role of Information Systems in The Preservation of Historic Monuments and Sustainable Development}

The field study, and the diagnosis of the various factors of housing development, in addition to the determinants that contribute to directing it in the city of Casablanca, allowed to define the elements of a field, which mainly contribute to affecting the pace of expansion of the built area and direct the housing in the study area, perhaps the most important of which is reflected in the topographical situation, housing and road axes Figures 3 and 4, then the non-buildable ranges or domains, like the inspired strip and waterways. And the preparation of layers according to the available data, allows performing the field analysis. We also refer to the presence of other elements that contribute to the dynamism of reconstruction, for example, the diverse status of real estate systems of land in the city of Casablanca, such as lands belonging to military properties, state lands and confinement, as well as private which we could not categorize or determine its area distribution, and generalized the dominance of the study. On the territory of the country that is considered the most prevalent, and is also the easiest in terms of mobilization, whether by the population or dirt groups for the purposes of construction and equipment [13-14].

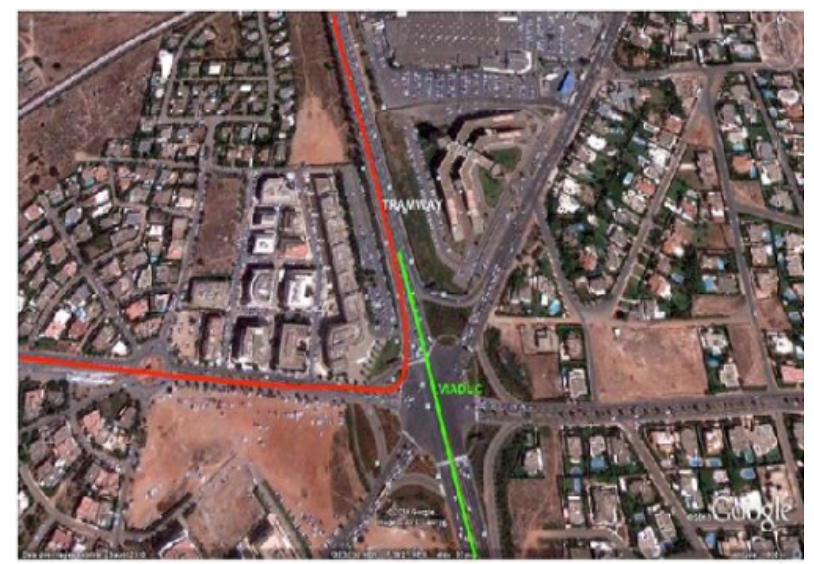

\section{Acknowledgements}

The authors thank the Casablanca Council and the Casablanca Urban Agency for all the information.

\section{REFERENCES}

[1] Belkhiri, B., Compte, J. P., El Khabouti, A., El Hamouri, A., \& Meryouh, D. Bilan de cinq années de Sécheresse au Maroc. Revue eau et développement N3,13-33. 1987.

Figure 3. Preparation of structured roads and Azbane junction 
[2] Joumady Kacem. Urbanisation et disparités spatiales au Maroc. In: Méditerranée, Littoralisation et disparités spatiales Machrek Maghreb. tome 91, pp. 93-100. 1999.

[3] Belinda Ng, Elizabeth, Eu Mee Chong, Implementation of Shallow Underpasses at an Urban Roundabout, IJATCSE. pp. 375-382, Volume 8, No.3, May - June 2019

[4] Daaif, J., Zerraf, S., Tridane, M., Benmokhtar, S., Belaaouad, S. Computer simulations as a complementary educational tool in practical work: Application of monte-carlo simulation to estimate the kinetic parameters for chemical reactions. IJATCSE. pp. 249-254. Volume 8, No.1.4, 2019

[5] Cesar A. Llorente, Jefferson O. Ang, Kenneth Robert O. Chan Shio, John Eric O. Chua, Elijah Ivin C. Cu Implementation of a Web based Weather Monitoring Station and Data Storage System. IJATCSE. Pp 527-530. Volume 8, No.3, May - June 2019.

[6] S. Kevin Andrews, V. Jeyabalaraja, M.S. Josephine. Vehicle Information System using R-Pi and Internet of Things IJATCSE. pp. 2156 - 2160. Volume 8, No.5, September October 2019.

[7] Eric Vaz, Pedro cabral, Mario caetano, M. Painho. Urban heritage endangerment at the interface of future cities and past heritage: A spatial vulnerability assessment. Habitat International 36(2):287-294. 2012

[8] Li Rui, Urban Heritage Conservation by GIS under Urban
Renewal, 44th ISOCARP Congress 2008.

[9] B. Zyani, « Habitat, contrainte foncière et développement urbain à Casablanca ", Habitat, état, société au Maghreb, sous la direction de R. Baduel, C.N.R.S., Paris 1988, p. 213-229.

[10] Dorning, M. A., Koch, J., Shoemaker, D. A., \& Meentemeyer, R. K. Simulating urbanization scenarios reveals tradeoffs between conservation planning strategies. Landscape and Urban Planning, 136(3), (2015). 28-39.

[11] Estoque, R. C., \& Murayama, Y. (2015). Intensity and spatial pattern of urban land changes in the megacities of Southeast Asia. Land Use Policy, 48, (2015), 213-222.

[12] Fan, C., \&Myint, S. A comparison of spatial autocorrelation indices and landscape metrics in measuring urban landscape fragmentation. Landscape and Urban Planning, 121, (2014). $117-128$.

[13] Bae, J., \&Ryu, Y. Land-use and land cover changes explain spatial and temporal variations of the soil organic carbon stocks in a constructed urban park. Landscape and Urban Planning, 136, (2015). 57-67.

[14] Bahi, Hicham \& Rhinane, Hassan \& Bensalmia, Ahmed \& Fehrenbach, U. \& Scherer, Dieter. Effects of Urbanization and Seasonal Cycle on the Surface Urban Heat Island Patterns in the Coastal Growing Cities: A Case Study of Casablanca, Morocco. Remote Sensing. 8. (2016). 829. 